\title{
Evaluation of Cytotoxicity and Genotoxicity of Water from Nag River, Nagpur, India
}

\author{
P. V. Hirapure*†, S. A. Paranjape*, V. S. Sarodaya*, B. A. Mehere* and V. J. Upadhye** \\ *Department of Biochemistry and Biotechnology, Dr. Ambedkar College, Deekshabhoomi, Nagpur, India \\ **Department of Microbiology, Parul Institute of Applied Sciences (PIAS), Parul University, Vadodara, Gujarat, India \\ †Corresponding author: P. V. Hirapure; pradiphirapure@gmail.com,dr.vijaysemilo@gmail.com
}

Nat. Env. \& Poll. Tech.

Website: www.neptjournal.com

Received: 23-01-2021

Revised: 29-03-2021

Accepted: 14-04-2021

Key Words:

Nag river

Cytotoxicity

Genotoxicity

Allium cepa.L.

Water pollution

Mutagenesis

\section{ABSTRACT}

The pollution of the river by man-made sewage and waste disposal is not only harmful to animals and plants in it but also for animals higher in the food chain including those close to the food chain. Water is the most vital natural substance, as it plays a role in nearly every aspect of human life. Therefore, there is a great need to ensure that the water used by humans should not contain hazardous substances. Water quality is directly linked to biological life. The Nag River flows from the Lava village of north Ambazari Lake and flows into the center of Nagpur city. As a result of rapid and unstoppable development, significant changes have taken place in the water quality of the Nag River. Because the Nag River's water is frequently used for irrigation, it should be tested for cytotoxicity and genotoxicity. Since the rate of cancer and genetic disorders has recently increased in the Nagpur region, the Nag River's water could be a source of carcinogens in the food chain, affecting the population. This study was conducted to analyze the impact of water collected from various points of the Nag River using Allium cepa as a model organism. The results of this study showed that all water samples from the Nag River cause a cytotoxic effect (20-23\%) and genotoxic effects (23-28\%) in Allium cepa cells. Therefore, before the use of Nag River water, it must be treated to diminish its harmful effect.

\section{INTRODUCTION}

Nagpur is the third biggest city in Maharashtra after Mumbai and Pune and it is one of India's quickest developing cosmopolitan cities. It is the winter capital of the province of Maharashtra and the second greenest city in India. Nagpur is home to a number of natural and man-made lakes, the largest of which being Ambazari Lake. This lake is where Nagpur's waterway begins. India has a vast and changing topography, which includes a large number of water bodies. Lakes and streams are now widely used for domestic purposes (Patil et al. 2017). Nagpur is fed by the Nag river, which gives the city its name. Originating from the Ambazari lake, the Nag river takes a winding path for approximately $16 \mathrm{~km}$ through the city before it joins another stream called Pili Nadi, which originates at another lake. This stream then merges into the Kanhan river on the outskirts of the city. Because Nagpur has experienced fast urbanization and migration to the city in the last five to six decades, there is increased use of water for domestic purposes, as well as, industrial production has increased, causing a sudden surge in sewage quantity (a meager grimy stream of water (Kalyani et al. 2017). Because of the value and importance of freshwater resources, they must be closely monitored biologically to meet water quality stand- ards (Puri et al. 2010). An enormous amount of wastewater from the Nagpur metropolitan region and numerous enterprises surrounding the urban areas is dumped into streams, such as the Nag river and its tributaries, contaminating both ground and surface water (Manzar et al. 2010). Because this river runs through a city with a population of around 50 lakh people, it is quite dirty. The Nag river was once a lifeline of the city. But today, the river's rich history has got buried in deep silt beneath the millions of litres of sewage flowing in it (Anparthi 2013). The Ambazari Lake which was the prime source of water to Nagpur city is filled with waste and sewage (which gives it an unnatural dark gray color and a foul smell), and despite receiving rainwater during monsoon it is not fit for consumption. Since such contaminated waste affects all metabolic and physiological activities, it is necessary to analyze the physiochemical attributes of water and propose measures to reduce contamination. All said and done, the sewage-water-flooded soils had higher $\mathrm{pH}$, natural carbon, and $\mathrm{CaCO}_{3}$. Surface skylines of soils (flooded/non-flooded) had higher groupings of DTPA-extractable $\mathrm{Fe}, \mathrm{Mn}, \mathrm{Cu}$, and $\mathrm{Zn}$, which decreased with depth. When compared to non-flooded soils, sewage-water-flooded soils are associated with moderately higher concentrations of DTPA-Fe, $\mathrm{Mn}, \mathrm{Cu}$, $\mathrm{Zn}, \mathrm{Pb}, \mathrm{Cr}$, and Album (Tayawade et al. 2010). 
Exposure to organic and inorganic chemicals over a long period of time can cause ecological health impairment of aquatic ecosystems causing considerable effects on aquatic biota including bioaccumulation of chemicals in organisms and biomagnification in higher trophic levels. Further, these can result in cytotoxic and genotoxic effects in the organisms (Daniels et al. 1989, Kannangara \& Pathiratne 2015). Therefore, many ecotoxicological studies focus on the assessment of physical and chemical environmental parameters and biological responses of organisms. However, recent ecotoxicological studies are paying more attention to using bioassays to assess the mutagenic and genotoxic effects of aquatic pollution (Kannangara \& Pathiratne 2015). These mutagenic and genotoxic studies have focused on assessing genotoxicity and mutagenic effects of fish species (Alimba et al. 2015, Carrasco et al. 1990) [12, 14], microorganisms (Buschini et al. 2001, Guan et al. 2017), mammals (Chiu et al. 2009, Kim et al. 2010), and higher plants (Iqbal et al. 2019) in relation to variation of chemical parameters in aquatic ecosystems

However, compared to other organisms Allium cepa is considered an efficient bioindicator in genotoxicity testing, because of the rapid root growth rate and reduced number of large chromosomes. A. cepa assay is commonly utilized as a short-term and cost-effective indicator of toxicity in monitoring water pollution in many parts of the world. This bioassay can provide valuable information on the presence of genotoxic and/or mutagenic compounds in surface waters and sediments of aquatic ecosystems. However, in Nagpur, a few tests have been carried out to analyze the physiochemical parameters of Bother stream water at various locations (Patil 2017, Manzar 2010, Tayawade et al. 2010) yet till today nobody evaluated the cytotoxicity and genotoxicity of the Bother Waterway Water. Therefore, the current study will use an A. cepa bioassay to assess the cytogenotoxic effects of water collected from several locations along the Bother Stream of the Nag River in Nagpur. By proving the ability of such substances to cause chromosomal changes in A. cepa root cells, the testing would provide important information concerning the presence of cytogenotoxic or potentially mutagenic substances in surface waters of the Bother stream.

\section{MATERIALS AND METHODS}

All the experimental work was completed at the Department of Biochemistry and Biotechnology, Dr. Ambedkar School, Deekshabhoomi, Nagpur during the period of October 2019 to Jun 2020. All the chemicals utilized in this investigation were bought from Hi-media Pvt. Ltd and (The basic purple onion, A. cepa) bulbs (2.5-2.8 cm in diameter) used in this study were purchased from a local market in Nagpur, Maharashtra (India).

Sample collection: The collection of water samples of Nag River which is spread over Nagpur city. Five different locations were randomly selected to collect the water sample which is given in Table 1. Water samples were collected in clean glass bottles and GPS values of that site were noted down.

\section{Allium cepa Test}

A commercial variety of common onions (Allium cepa) was used for the determination of different toxicity end points of meristematic cells. Equal sized healthy onion bulbs were chosen and the outer scales of bulbs were removed by gently scraping to make the apices of root primodia exposed. Scarped onion bulbs were germinated in glass test tubes containing distilled water for 24 hours in the dark. The $A l$ lium cepa bioassay in accordance with Grant (1982) with some modifications was conducted using water samples collected from the study sites. After 24 hours, onion bulbs were exposed to the exposure media $(70 \mathrm{~mL}$, Nag River sample taken from each site) in the glass tubes at the time of processing. For each exposure media 10 onion bulbs were tested. Bulbs with exposure media were kept in dark to avoid the direct sunlight.

After 48 hours of exposure, root lengths of randomly selected five onion bulbs from each exposure media were measured in millimeters. Root tips (5-6 from each onion bulb) of 1-2 mm length were processed for microscopic studies of toxicity end points. Root tips were fixed in ethanol: glacial acetic acid $(3: 1, \mathrm{v} / \mathrm{v})$ solution for overnight at $4^{\circ} \mathrm{C}$. Root tips were transferred into $70 \%$ alcohol and stored at $4{ }^{\circ} \mathrm{C}$ until the time of processing.

Table 1: River Water was collected from five different locations of Nag River, Nagpur.

\begin{tabular}{|lll|}
\hline Samples ID & Water collected from different area & GPS Location \\
\hline Sample 1 & Rashimbagh Darsa Road & $21^{\circ} 08^{\prime} 19.9^{\prime} \mathrm{N} 79^{\circ} 06^{\prime} 31.3^{\prime \prime} \mathrm{E}$ \\
Sample 2 & Gangabai Ghat Road & $21^{\circ} 08^{\prime} 26.2^{\prime \prime} \mathrm{N} 79^{\circ} 07^{\prime} 13.0^{\prime} \mathrm{E}$ \\
Sample 3 & Near Airtel express & $21^{\circ} 08^{\prime} 30.0^{\prime} \mathrm{N} 79^{\circ} 07^{\prime} 32.5^{\prime} \mathrm{E}$ \\
Sample 4 & Near RajatSankul apartment & $21^{\circ} 08^{\prime} 14.3^{\prime} \mathrm{N} 79^{\circ} 05^{\prime} 43.0^{\prime} \mathrm{E}$ \\
Sample 5 & Rashimbagh road ( Plant growing side) & $21^{\circ} 08^{\prime} 18.4^{\prime} \mathrm{N} 79^{\circ} 06^{\prime} 21.0^{\prime} \mathrm{E}$ \\
\hline
\end{tabular}


When processing the root tips, they were hydrolyzed in hydrochloric acid $(1 \mathrm{~N})$ solution for 5 minutes at $60^{\circ} \mathrm{C}$ and washed with distilled water. Root tips were then placed in watch glasses containing acetocarmine for 30 minutes to allow the stain to penetrate to the primordial cells. After staining, root tips were placed on glass slides and a slight pressure was applied on the cover slip to squash the tip cells over the slide. Prepared slides for each exposure medium were observed under the light microscope at 400x magnification to score mitotic stages, occurrence of micronuclei, and nuclear abnormalities in the interphase cells (Fiskesjo 1985, 1988).
Mitotic index was calculated as the number of dividing meristematic cells into 100 total meristematic cells by counting 1000 meristematic cells in each slide

Mitotic index $=$ Number of dividing meristemetic cells / total meristemetic cells $(500) \times 100$

\section{RESULTS AND DISCUSSION}

Effect of water samples on cell division process, cytological and chromosomal characteristics were assessed by A. серa test and results given in Tables 2, 3 and 4, and Figs. 1 and 2.

Table: 2. Effect of water sample collected from different sites of Nag river on cell division.

\begin{tabular}{|c|c|c|c|c|c|c|c|}
\hline & No. of dividing cells & Prophase & Pro-metaphase & Metaphase & Anaphase & Telophase & $\mathrm{MI}$ in $\%$ \\
\hline Control & $163 \pm 3.05$ & $78 \pm 1.02$ & $24 \pm 2.08$ & $21 \pm 1.52$ & $29 \pm 2.51$ & $11 \pm 1.15$ & 32.6 \\
\hline Sample 1 & $50 \pm 2.05$ & $20 \pm 1.03$ & $6 \pm 0.33$ & $8 \pm 2.52$ & $9 \pm 1.15$ & $7 \pm 0.57$ & 10 \\
\hline Sample 2 & $48 \pm 1.05$ & $18 \pm 1.52$ & $8 \pm 0.12$ & $7 \pm 1.52$ & $10 \pm 2.51$ & $5 \pm 1.15$ & 9.6 \\
\hline Sample 3 & $43 \pm 1.06$ & $17 \pm 0.50$ & $6 \pm 0.60$ & $6 \pm 0.57$ & $8 \pm 1.15$ & $6 \pm 0.72$ & 8.6 \\
\hline Sample 4 & $49 \pm 1.52$ & $19 \pm 0.8$ & $7 \pm 1.01$ & $8 \pm 1.15$ & $9 \pm 1.15$ & $6 \pm 2.51$ & 9.8 \\
\hline Sample 5 & $40 \pm 2.51$ & $17 \pm 1.01$ & $5 \pm 0.91$ & $7 \pm 0.57$ & $6 \pm 0.57$ & $5 \pm 0.72$ & 8.0 \\
\hline
\end{tabular}

Data are presented as mean \pm standard deviation $(\mathrm{SD}), \mathrm{MI}-$ mitotic index

Table 3: Chromosomal aberrations in Allium cepa root tip cells exposed to the Nag river water samples.

\begin{tabular}{|lllllllll|}
\hline & Bridges & Breaks & lagging & Stickiness & Abnormal spiralisation & Multipolarity & $\begin{array}{l}\text { Abnormal Ki- } \\
\text { netics }\end{array}$ & $\begin{array}{l}\text { Total No. of Aberrant } \\
\text { cells }(\%)\end{array}$ \\
\hline Control & $00 \pm 00$ & $00 \pm 00$ & $01 \pm 0.57$ & $01 \pm 0.02$ & $00 \pm 00$ & $01 \pm 0.57$ & $01 \pm 0.57$ & $04(0.8)$ \\
Sample 1 & $09 \pm 0.57$ & $17 \pm 2.52$ & $00 \pm 00$ & $78 \pm 2.52$ & $13 \pm 0.57$ & $11 \pm 2.52$ & $13 \pm 1$ & $141(28.00)$ \\
Sample 2 & $07 \pm 1.15$ & $11 \pm 1.15$ & $02 \pm 0.57$ & $67 \pm 1.51$ & $12 \pm 2.15$ & $09 \pm 0.57$ & $12 \pm 2.51$ & $120(24)$ \\
Sample 3 & $09 \pm 2.15$ & $10 \pm 1.52$ & $01 \pm 0.02$ & $71 \pm 0.57$ & $9 \pm 1.15$ & $07 \pm 1.52$ & $11 \pm 2$ & $118(23.6)$ \\
Sample 4 & $09 \pm 0.57$ & $09 \pm 1.15$ & $00 \pm 00$ & $74 \pm 2.52$ & $16 \pm 1.52$ & $13 \pm 2.51$ & $15 \pm 1.52$ & $136(26.2)$ \\
Sample 5 & $10 \pm 0.51$ & $12 \pm 2.08$ & $03 \pm 0.57$ & $64 \pm 3.15$ & $14 \pm 2.52$ & $09 \pm 1.15$ & $12 \pm 2.51$ & $124(24.8)$ \\
\hline
\end{tabular}

Data are presented as mean \pm standard deviation $(\mathrm{SD})$

Table: 4: Cytotoxic effects of different collected Nag River water on root tips of Allium cepa.

\begin{tabular}{|lllllll|}
\hline & $\begin{array}{l}\text { Cells without nu- } \\
\text { cleus }\end{array}$ & $\begin{array}{l}\text { Morphological alter- } \\
\text { ations }\end{array}$ & Plasmolysed cells & BNC & MNC & $\begin{array}{l}\text { Total no. of aberrant cells } \\
(\%)\end{array}$ \\
\hline Control & $00 \pm 00$ & $01 \pm 0.57$ & $01 \pm 0.5$ & $01 \pm 0.57$ & $00 \pm 00$ & $03(0.6)$ \\
Sample 1 & $07 \pm 0.57$ & $20 \pm 2.52$ & $34 \pm 2.52$ & $07 \pm 1.51$ & $50 \pm 3.02$ & $118(23.06)$ \\
Sample 2 & $08 \pm 1.15$ & $15 \pm 3.08$ & $40 \pm 1.52$ & $04 \pm 1.52$ & $44 \pm 2.52$ & $110(22.00)$ \\
Sample 3 & $07 \pm 0.57$ & $24 \pm 2.15$ & $30 \pm 2.52$ & $06 \pm 0.57$ & $40 \pm 2.52$ & $107(21.4)$ \\
Sample 4 & $07 \pm 1.52$ & $22 \pm 1.52$ & $25 \pm 2.15$ & $04 \pm 1.15$ & $37 \pm 0.57$ & $100(20.00)$ \\
Sample 5 & $08 \pm 1.00$ & $19 \pm 1.02$ & $29 \pm 3.08$ & $07 \pm 1.52$ & $49 \pm 1.15$ & $112(22.4)$ \\
\hline
\end{tabular}

Data are presented as mean \pm standard deviation (SD); BNC-nucleated cells, MNC- micronucleated cells. 
The mitotic index of the A. cepa root tip cells in the present study ranged from $8 \%$ to $10 \%$ in Nag River water samples which were low compared to control (32\%)
(Fig. 3). A mitotic index of less than $22 \%$ is considered fatal to organisms (Antonise-Wiez 1990) As a result, the mitotic indices measured in this study are frequently regarded

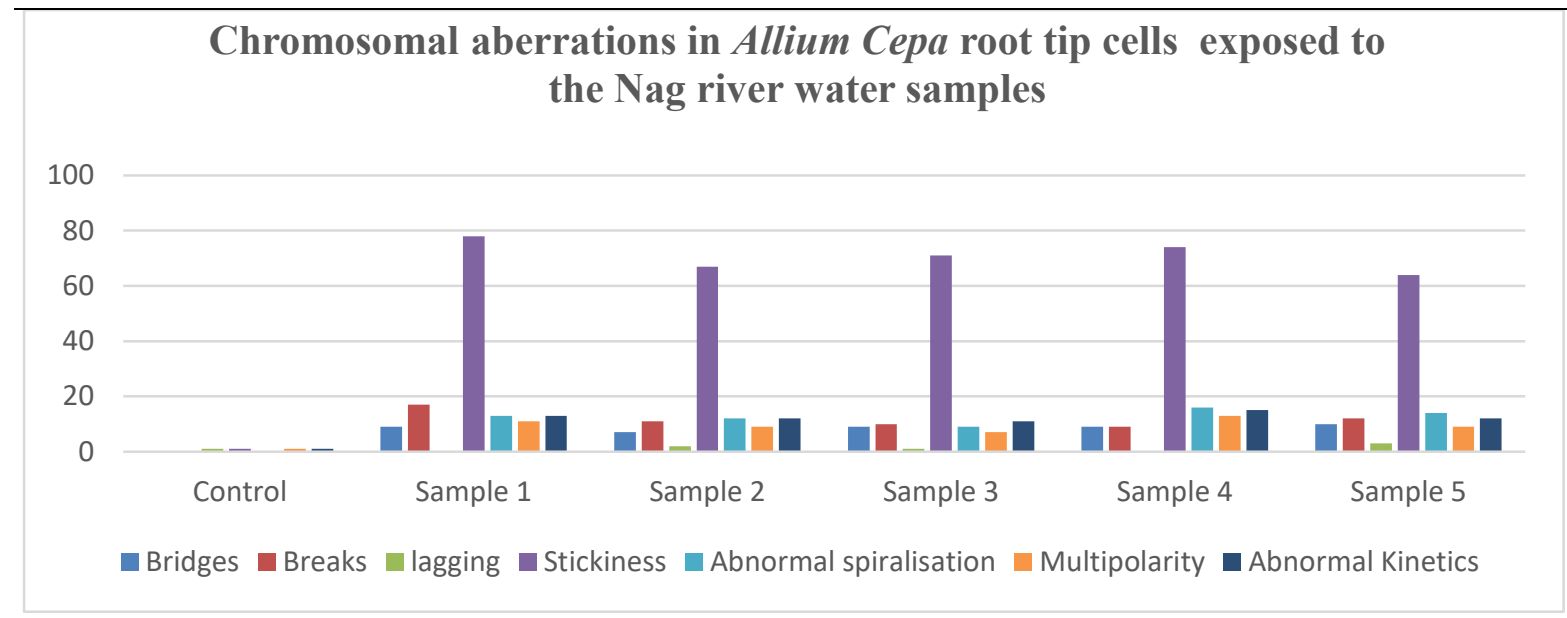

Fig. 1: Chromosomal aberrations in Allium cepa root tip cells exposed to the Nag river water samples.

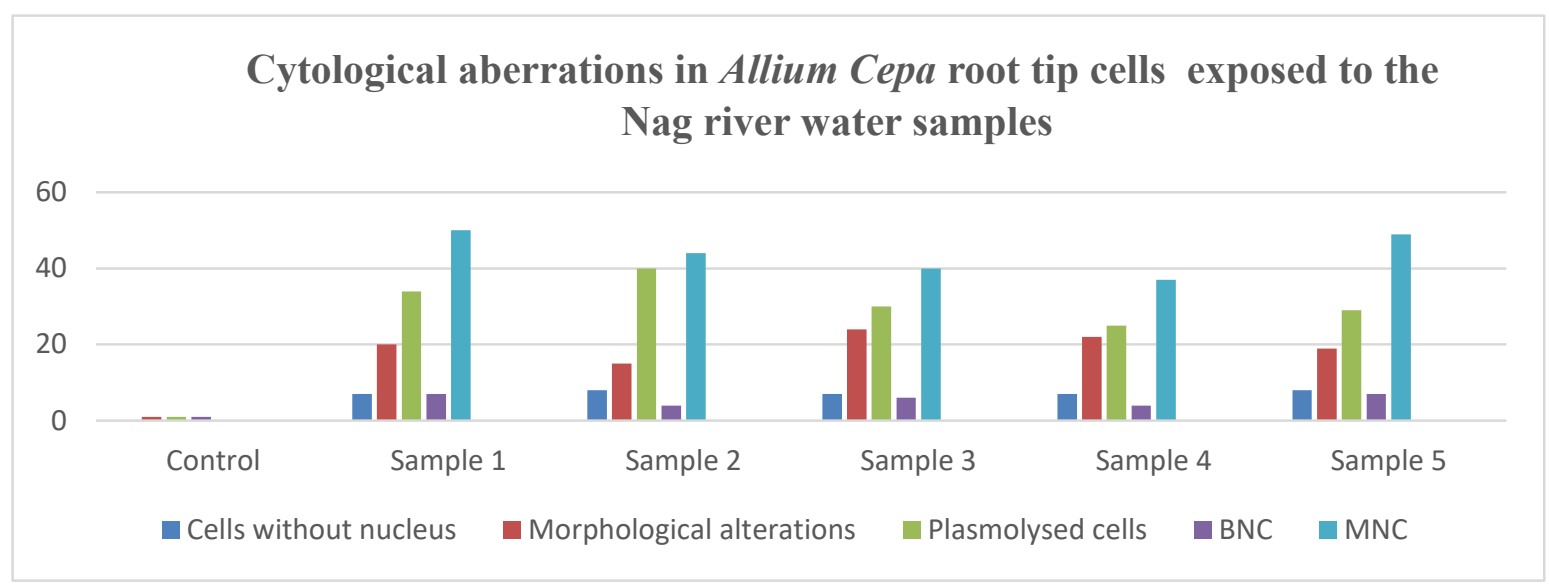

Fig. 2: Cytological aberrations in Allium cepa root tip cells exposed to the Nag river water samples.

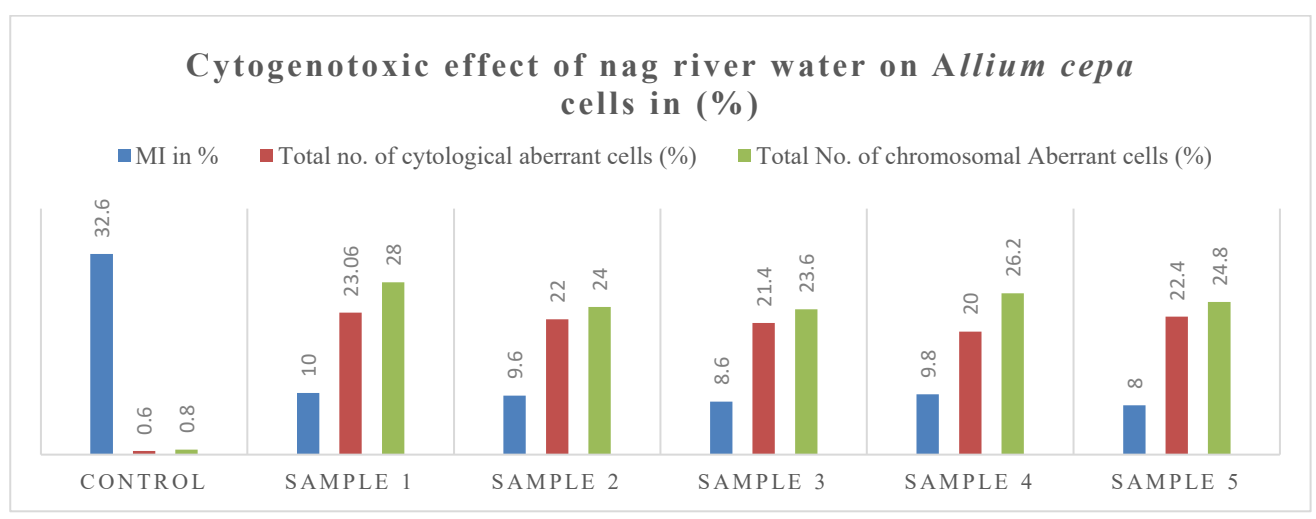

Fig. 3: Cytogenotoxic effect of nag river water on Allium cepa cells in (\%). 
as harmful and indicate high cytotoxic effects within the environment.

The presence of chromosomal abnormalities in A. cepa root tip cells indicates that genotoxic compounds may be present in the exposed medium (Kannangara \& Pathiratne 2015, Boumaza et al. 2016).

After exposure to the Nag river water sample, chromosomal abnormalities in A. cepa root tip cells were observed. Anaphase bridges, breaks, chromosomal lagging and stickiness, aberrant spiraliation of chromosomes, multipolarity, and polyploidy were all observed, as shown in Fig. 4.

After treatment with Nag river water, cytological abnormalities were identified during the cell cycle. In all water samples except the control, anomalies such as cells without nucleus, bi-nucleated cells, and morphological alterations were observed. Fig. 5 shows a few examples of cytological changes.
Studies have proven that compounds such as poly aromatic hydrocarbons, copper, arsenic, and other industrial effluents have been shown to have cytotoxic and genotoxic effects in A. cepa root tip cells (Kannangara \& Pathiratne 2015, Samuel et al. 2010, Da Costa et al. 2012, Olorunfemi 2011)

The A. cepa assay is a vital in-vivo assay in which the roots develop in direct contact with the substance of interest, allowing for the prediction of possible DNA damage in humans (Nefic et al. 2013). The test used in this study allows for the evaluation of several genetic endpoints that arise as a result of exposure to various water samples collected from the Nag River in Nagpur, Maharashtra. All 5 samples caused significant inhibition of MI in Allium cepa meristem cells and induced chromosomal aberrations, nuclear abnormalities and micro nucleated cells (MNCs).

The mitotic index decreased in all five experimental water samples when compared to the control. The cytotoxic and

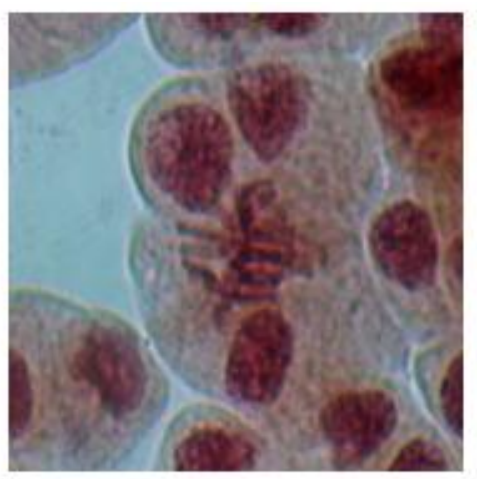

(a)Polyploidy

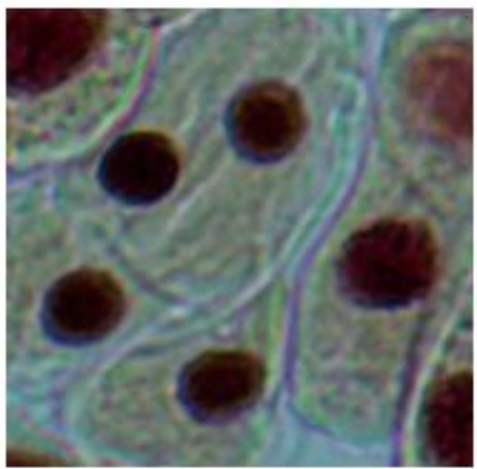

(e)Sticky nucleus

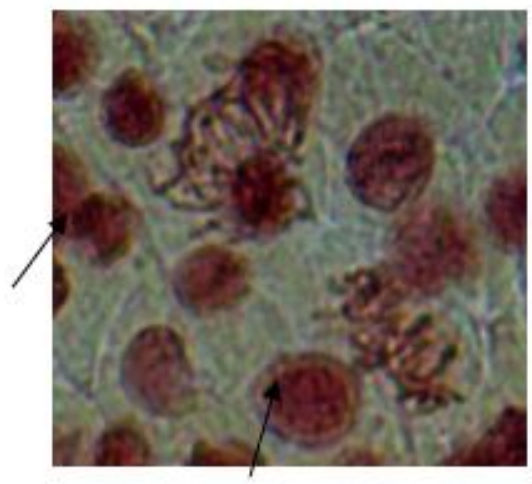

(b) Multipolarity \& (c) Lagging

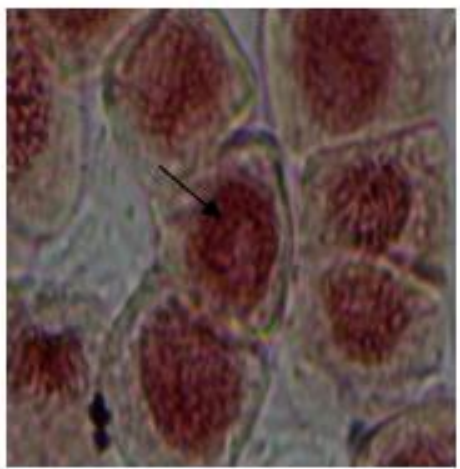

(f) Abnormal kinetics

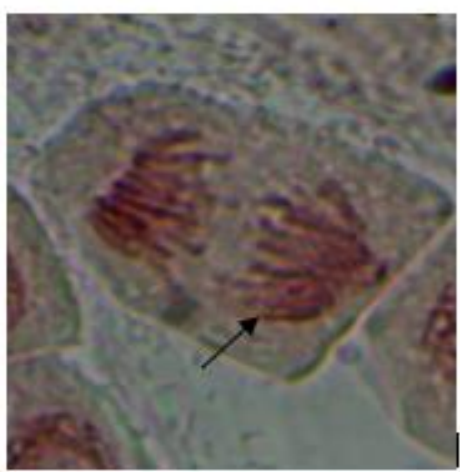

(d) Bridges

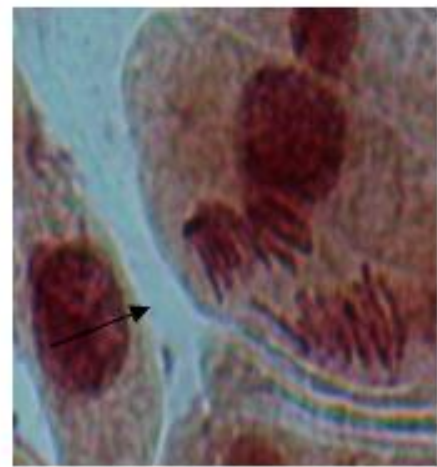

(g) Breaks

Fig. 4: Photomicrographs of CAs induced by Nag River water in root cells of Allium cepa. 


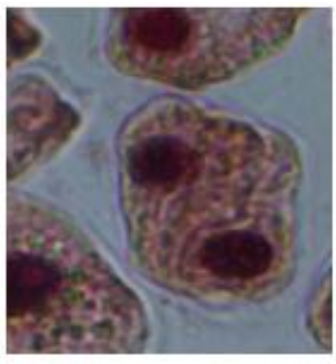

(a)Binucleated cells

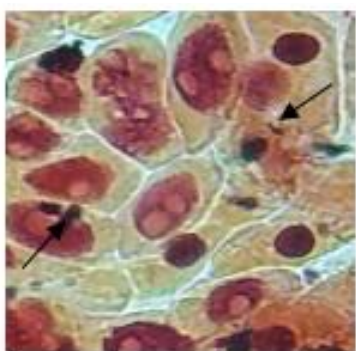

(b) Micro-nucleated cells

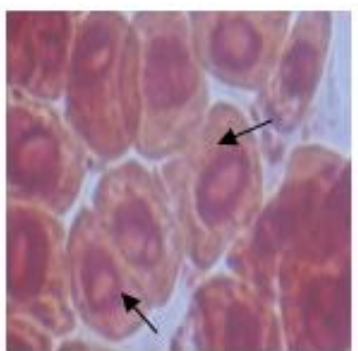

(c) Plasmolysed cells

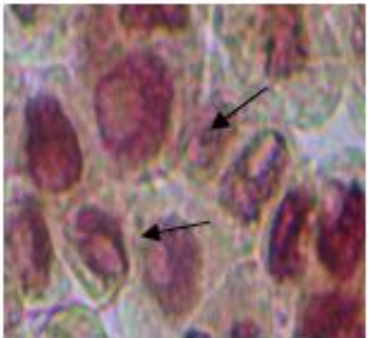

(d) Morphological alterations

Fig. 5: Cytological aberrations in Allium cepa meristem cells exposed to Nag River water

genotoxic potential of Nag river water samples is determined by changes in MI of Allium cepa cells. The sample with the most chromosomal abnormalities was no. 1. (28\%). The examination of various chromosomal abnormalities types at various stages of the cell cycle allows for a more thorough investigation of the impacts of the Nag river water sample. Breakages may occur and subsequent inhibition of repair mechanisms may lead to base mismatch, mutation and CAs such as fragmented chromosomes and DNA breaks (Nefic et al 2013).

All water samples tested from different points along the Nag River had bridges, breaks, lags, multi-polar anaphase chromosomes, and aberrant spiralization. The findings revealed that all Nag river water samples were capable of inhibiting normal cell division and causing deadly chromosomal abnormalities. Stickiness is due to inter-chromosomal linkages of sub-chromatid strands coupled with excessive formation of nucleoproteins and inappropriate protein-protein interaction (Nefic et al. 2013).

Cytological aberrations are characterized by BNC, plasmolyzed cells, and micronucleus formation as a result of exposure to Nag river Water samples. Also, we observed alterations in the shape and size of cells in all collected Nag river water samples.

\section{CONCLUSION}

Domestic as well as industrial activities are important sources of pollution during the flow of these rivers. Domestic sources as compared to industrial sources exceed. substantially in terms of organic load addition into the River. The predominant source is untreated sewage discharged by Nagpur Municipal Corporation into Nag and Pili Rivers.

The findings of this study revealed that the water of the Nag River is highly cytotoxic and genotoxic, making it unsafe for drinking and irrigation. No one should grow any vegetables or crops near the Nag River because toxic substances could enter the food chain and cause diseases due to the phenomenon of biomagnification and bioaccumulation. It's critical to identify the composition and speciation of those cytogenotoxic compounds in the tropical climate, as well as to provide cleanup or treatment options to address this environmental and public health risk. Furthermore, continual water quality monitoring and management are critical for maintaining the ecosystem's ecological health.

\section{ACKNOWLEDGMENTS}

The authors wish to acknowledge the Principal of Dr. Ambedkar College, Deekshabhoomi, Nagpur (India), for providing the laboratory facilities to conduct this research and $\mathrm{Mr}$. Avinash Chavhan's laboratory assistant for the kind support.

\section{REFERENCES}

Alimba, C.G., Ajayi, E.O., Hassan, T., Sowunmi, A.A. and Bakare, A.A. 2015. Cytogenotoxicity of abattoir effluent in Clariasgariepinus (Burchell, 1822) using the micronucleus test. Chinese J.Biol., 2015: 56-71

Anparthi, A. 2013. Nag river looks like a sewage drain. Times of India, Times News Network, Mumbai, India.

Antonise-Wiez, D. 1990. Analysis of the cell cycle in the root meristem of Allium cepa under the influence of ledakrin. Folia Histochem. Cytobiol., 28(1-2): 79-95.

Boumaza, A., Lalaoui, K., Khallef, M., Sbayou, H., Talbi, H. and Hilali, A. 2016. Assessment of cytotoxic and genotoxic effects of Clodinafop-propargyl commercial formulation on Allium cepa L. J. Mater. Environ. Sci., 7(4): 1245-1251.

Buschini, A., Cassoni, F., Anceschi, E., Pasini, L., Poli, P. and Rossi, C. 2001. Urban airborne particulate: Genotoxicity evaluation of different size fractions by mutagenesis tests on microorganisms and comet assay. Chemosphere, 44(8): 1723-1736.

Carrasco, K.R., Tilbury, K.L. and Myers, M.S.1990. Assessment of the piscine micronucleus test as an in situ biological indicators of chemical contaminant effects. Can. J. Fish. Aquat. Sci., 47(11): 2123-2136.

Chiu, W. A., Okino, M. S. and Evans, M. V. 2009. Characterizing uncertainty and population variability in the toxicokinetics of trichloroethylene and metabolites in mice, rats, and humans using an updated database, physiologically based pharmacokinetic (PBPK) model, and Bayesian approach. Toxicol. Appl. Pharmacol., 241(1): 36-60. 
Daniels, S.A., Munawar, M. and Mayfield, C.I. 1989. An improved elutriation technique for the bioassessment of sediment contaminants. Hydrobiologia, 188(1): 619-631.

Da Costa, T. C., de Brito, K. C. T., Rocha, J. A. V., Leal, K. A., Rodrigues, M. L. K., Minella, J. P. G., ... \& Vargas, V. M. F. 2012. Runoff of genotoxic compounds in river basin sediment under the influence of contaminated soils. Ecotoxicol. Environ Safety, 75: 63-72.

Fiskesjo, G. 1985. The Allium test is a standard in environmental monitoring. Hereditas, 102(1): 99-112.

Fiskesjo, G. 1988. The Allium test: An alternative in environmental studies: The relative toxicity of metal ions. Mutat. Res/Fund. Mol. Mech. Mutagen., 197(2): 243-260.

Grant, W.F. 1982. Chromosome aberration assays in Allium: A report of the US Environmental Protection Agency gene-tox program. Mutat Res-Rev. Gene. Toxicol., 99(3), 273-291.

Guan, Y., Wang, X., Wong, M., Sun, G., An, T., Guo, J. and Zhang, G. 2017. Evaluation of genotoxic and mutagenic activity of organic extracts from drinking water sources. PloS One, 12(1): e0170454.

Iqbal, M., Abbas, M., Nisar, J., Nazir, A. and Qamar, A. 2019. Bioassays based on higher plants as excellent dosimeters for ecotoxicity monitoring: A review. Chem Int., 5(1), 1-80.

Kalyani, M. 2017. Nag river's rich history drown in silt. Articulations, 2017: 3-9

Kim, Y. J., Yang, S. I. and Ryu, J. C. 2010. Cytotoxicity and genotoxicity of nano-silver in mammalian cell lines. Mol. Cell. Toxicol. 6(2): 119-125.

Kannangara, D.N.M. and Pathiratne, A. 2015. Toxicity assessment of industrial wastewaters reaching DanduganOya, Sri Lanka using a plant-based bioassay. J. Natl. Sci. Found Srilanka, 43(2): 153-163

Manzar, A. 2010. Report of Government of India Ministry of Water Resources. Central Groundwater Board, India

Nefic, H., Musanovic, J., Metovic, A. and Kurteshi, K. 2013. Chromosomal and nuclear alterations in root tip cells of Allium cepa $\mathrm{L}$. induced by alprazolam. Med Arch., 67(6): 388.

Olorunfemi D.I. 2011. Cytotoxic and genotoxic effects of Cassava effluents using the Allium cepa bioassay. Res. J. Mutagen, 1(1), 1-9

Patil, A.M. 2017. Assessment of Water Quality Parameters of Nag River Flowing through Nagpur, Maharashtra. Monitoring Central Organization, Central Water Commission Nagpur, India

Puri, P.J., Yenkie, M.K.N., Battalwar, D.G., Gandhare, N.V. and Dhanorkar, D B. 2010. Study and interpretation of physico-chemical characteristics of lake water quality in Nagpur city (India). Rasayan J. Chem., 3(4): 800-810.

Samuel, O.B., Osuala, F.I. and Odeigah, P. G.2010. Cytogenotoxicity evaluation of two industrial effluents using Allium cepa assay. Afr. J. Environ. Sci. Tech., 4(1): 123-140.

Tayawade, S.S. and Prasad, J. 2008. Characterization of sewage-water-irrigated and non-irrigated soils in nag river ecosystem of Nagpur, Maharashtra. J. Indian Soc. Soil Sci., 56(3): 247-253. 